\title{
Introduction to Anthropology
}

Pontianak: STAIN Pontianak Press, 2013

\author{
By Zaenuddin Hudi Prasojo
}

Reviewed by

Aspari Ismail

(The Forum of Lingkar Pena of West Kalimantan, Pontianak)

\section{ANTHROPOLOGY: A NECESSITY!}

Anthropology is the study of mankind (anthropos). Etymologically, anthropology comes from the word anthropos meaning man and logos meaning knowledge. Anthropology looks at humans as something complex in terms of physical, emotional, social, and cultural complexity. Anthropology also refers to the science of humans and their culture.

Since anthropology is one of the social sciences, of course it is a necessity, and undoubtedly very important considering humans as social creatures cannot possibly loose interacting with each other. Studying anthropology will create tolerance and a peaceful life. Being unable to understand each other has resulted in prejudice, quarrel, brawl, and even war. Differences are often considered a threat, but when managed properly, they that could be a beauty, like a variety of colorful flowers in a garden.

Things that occur in life on a small scale: in the household, between ethnic and religious groups, even among a religious group to elements of a nation, and between countries. Can anthropology solve life problems mentioned? Certainly, anthropology has a significant contribution. It is the study of all kinds of things that have to do with human beings. At the very least, someone who has studied or learned anthropology will further acknowledge and understand that every people, ethnic group, religion, community and nation has certain a distinctive and particular character. Thus, it will promote mutual tolerance and peace.

The best way to learn it is by combining the theory with the practice. One of the books worth reading is "Introduction to Anthropology" written by Dr. Zaenuddin, MA. In this book, readers will find 10 chapters with a variety of theories. Readers will be able to choose an interesting part to read without necessarily reading one chapter after another. Each chapter will be reviewed below.

Chapter I features the important figures and theories of anthropology. 
Here, readers will be presented with the history and development of the anthropological theories as well as prominent figures of reference. From the history of anthropology as a science that started with the study of the characteristics of the human body to the recent development, all is described clearly.

Chapter II presents the material related to culture and language. In this chapter, the author explains the definition and meaning of culture; characteristics of culture; existence and culture; relationship between culture with society; culture and the individual; culture and change; the origins of language; languages within the framework of life; language and conceptualization of culture; and the process of learning a language.

Chapter III discusses the infrastructure. In this section readers will be presented with the notion of infrastructure; production mode of hunting and concocting; development of energy; rice-field agriculture; production mode of slash and burn agriculture; production mode of livestock farming; population; human sexuality; children; energy transformation and technology.

Chapter IV exclusively covers the structure. This part outlines economic organizations; redistribution; the origins of the states; class society; casteism in India; kinship, descent and locality; ethnicity, race and racism; laws, rules and war in tribal communities; domestic organizations; and gender hierarchy.

Chapter V contains discussion on superstructure. In this section, the author discussed the sense and scope of the superstructure; religion and culture which consist of 1) religion and society; 2) types of religion; 3) religions and social stability; religion and family; religion and social change; formation of attitudes and mentality; social sciences; psychology; the types of religious organizations; religion and magic; religion and taboos; culture and personality; Freud's influence; what art is; art and culture; art and politics; art and its evolution.

Chapter VI deals with physical anthropology. Discussions about humans and animals; evolutionary biology; human history; homo sapiens; old world culture; race and human variation; the problem of race; the pattern of life; cultural evolution; multi-linear evolution; as well as universal and multi-linear evolution comparison.

Chapter VII is seriously discusses the methodology of anthropology. The author describes various methods that can be used in anthropology, phenomenology; symbolic interactionism; grounded theory; cross cultural comparison; thick description; ethno-methodology; case studies; survey methods; ethnography; and the method of the use of documentation (historiography).

In Chapter VIII, the mapping between the city and the village anthropology 
is discussed. This section describes the characteristics of the community; the concept of urbanization; four characteristics of the cities in Indonesia (diachronic perspective); five characteristics of the cities in Indonesia; types and images of world's cities; village conceptualization; moral economy of farmers; dilemma of the peasantry; ideology of the peasant movement; and resistance of the peasantry.

In Chapter IX, the writer predicts the future of Anthropology. Among the discussions: the bounded system to a borderless society; the contemporary studies of anthropology; need to examine isolated tribes; modern ethnicity; anthropology among other social sciences; Anthropology and globalization; Anthropology and leadership; relevance and application of the science of anthropology; modern anthropology; and the postmodern anthropology.

Chapter X concludes with a discussion of globalization. The author explains the notion of globalization; the global trends; the influence of globalization in Indonesia; influence in the world of education; the process of globalization; aspects of globalization; the impact of globalization; as well as the role of the community in local development to enter the global community.

With a complete menu, I think the book is more than just 'An Introduction to Anthropology '. The use of the word 'introduction' is as a form of humility. The language used is quite simple and anyone who reads it will be easy to digest the contents of the book. It's just that unfortunately I found the imperfection of the editing. It somehow distracts the readers from their convenience of reading. However, apart from a bit of a shortage, this book nonetheless is important to read. With embossed title on the cover, this book looks dashing and luxurious.

As already mentioned above, learning all sciences, including anthropology, is combining the theory and the practice. A bunch of theories is useless without knowledge in practice. The book, written Dr. Zaenuddin Prasojo, is more than enough to expand our horizon on knowing about and understanding anthropology. Now you can start your own research on the character, habits and culture of a society. Those who often associate with various characters are usually more mature and open. Happy reading and enjoy this book. 